\title{
Czym jest psyche podwładnych dla jej znawców? Benjamin Lee Whorf, pojęcie sposobu rozpatrywania i problem uprzedmiotowienia
}

\author{
Jerzy Stachowiak \\ Uniwersytet Łódzki
}

DOI: http://dx.doi.org/10.18778/1733-8069.16.4.02

\section{Słowa kluczowe: dyskurs, \\ uprzedmiotowienie, Benjamin Lee \\ Whorf, psychologia, kapitalizm}

\begin{abstract}
Abstrakt: W niniejszym artykule przedstawiona zostaje propozycja wykorzystania w badaniach nad dyskursem niektórych idei Benjamina Lee Whorfa. Whorf na ogół nie inspiruje analityków dyskursu, a jednak obecna w jego dorobku problematyka tak zwanej segmentacji doświadczenia mogłaby się przyczynić do tematyzacji ważnych zjawisk współczesnej kultury. Przy czym pojęcie segmentacji nie może być w prosty sposób zapożyczone z etnolingwistyki Whorfa. Musi ono zostać istotnie przetworzone na użytek badań nad dyskursem. W wyniku próby takiego przetworzenia zaproponowane zostaje pojęcie „sposobu rozpatrywania”. Następnie przedstawiony zostaje przykład analizy tekstu. Ma on naprowadzić na sens i możliwości empirycznego zastosowania pojęcia „sposobu rozpatrywania”. Podstawą analizy jest fragment tekstu doradczego z zakresu psychologii pracy. Artykuł kończy się uwagami dotyczącymi procesu cywilizowania uprzedmiotowienia, zwłaszcza związków miedzy sposobem rozpatrywania psyche podwładnych a makrospołecznymi przemianami dyskursu publicznego.
\end{abstract}

Jerzy Stachowiak, socjolog, adiunkt w Zakładzie Badań Komunikacji Społecznej Instytutu Socjologii Uniwersytetu Łódzkiego. Główne zainteresowania badawcze: teoria społeczna, analiza dyskursu publicznego, społeczeństwo i gospodarka wiedzy. Publikował m.in. w "Studiach Socjologicznych”, „Przeglądzie Socjologicznym”, „Societas/Communitas".

\author{
Adres kontaktowy: \\ Zakład Badań Komunikacji Społecznej \\ Instytut Socjologii \\ Wydział Ekonomiczno-Socjologiczny \\ Uniwersytet Łódzki \\ 90-214 Łódź, ul. Rewolucji 1905 r. 41/43 \\ e-mail: jerzy.stachowiak@uni.lodz.pl
}




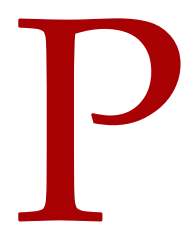

olska, jak i światowa literatura wspominają o Benjaminie Lee Whorfie przede wszystkim w kontekście problematyki relatywizmu językowego lub tak zwanej hipotezy Sapira-Whorfa. Tym mianem, łączącym nazwisko Edwarda Sapira (nauczyciela) i Whorfa (ucznia), zwykło się określać wielorako interpretowane ujęcie wzajemnych zależności między językiem, myśleniem i kulturą. Mowa o „tak zwanej” hipotezie, ponieważ nie jako hipotezę Whorf ją sformułował, tylko jako zasadę (principle). Zasada stała się hipotezą za sprawą tych, którzy zamierzali poddać stanowisko Whorfa empirycznemu (zwłaszcza eksperymentalnemu) sprawdzeniu. Do dziś nawiązuje się do niej przede wszystkim poprzez próby dostarczenia dowodów za lub przeciw niej, argumentów przesądzających o jej teoretycznych niedostatkach lub zaletach, propozycji empirycznego jej potwierdzenia lub obalenia (por. Gumperz, Levinson 1996; Sweeney 2009: 39-54; Everett 2013). W miarę podejmowania tych prób poznawczy status zasady relatywizmu stał się równie kontrowersyjny co akademicka reputacja jej autora. Jedni widzą w Whorfie amatora popełniającego podstawowe błędy badawcze (por. Lakoff 2011), inni zaś - geniusza o poważnym dorobku i niespotykanej wyobraźni (por. Lucy 1992).

Treść zasady relatywizmu jest często traktowana jako wyraz całościowego stanowiska Whorfa - i tak też polskie językoznawstwo najczęściej ją rozważa. Jeśli można mówić o wykorzystaniu w Polsce na szerszą skalę inspiracji Whorfem, to znaleźć je można zwłaszcza w badaniach z zakresu językoznawstwa kognitywnego (Grzegorczykowa, Pajdzińska 1996; Tabakowska 2001). Odnajduje się je jednak zwłaszcza w pracach na temat językowego obrazu świata, które między innymi Jerzy Bartmiński (2012), a także jego współpracownicy i akademiccy kontynuatorzy (Głaz, Danaher, Łozowski 2013) umiejscawiają w et- nolingwistyce - dziedzinie, której nazwę proponował właśnie Whorf. Polska literatura filozoficzna otrzymała obszerniejsze omówienie prac Whorfa od Teresy Hołówki (1986) - autorki ich przekładu, zatytułowanego Język, myśl i rzeczywistość. Mimo to Whorf nie przestaje być kojarzony niemal wyłącznie jako autor ledwie kilku fragmentów ujętych w artykułach przygotowanych dla publiczności spoza kręgu akademickiej lingwistyki (między innymi Językoznawstwo jako nauka ścisła czy Nauka a jezykoznawstwo opublikowanych w „Technology Review” oraz Jezyk, umyst, rzeczywistość ogłoszony w "Theosophist” - wydawanym w Indiach czasopiśmie Towarzystwa Teozoficznego). Teksty Whorfa, które nie weszły do pierwszego wydania zbioru Language, Thought, and Reality, nadal nie są właściwie w ogóle tematem komentarzy.

W innych dyscyplinach naukowych poznaje się Whorfa jako antropologa, którego nazwisko wymieniane jest na propedeutycznych kursach z nauk społecznych. Jednak niektóre antologie tekstów klasycznej antropologii $w$ ogóle nie uwzględniają Whorfa (por. Godlewski i in. 2001; Kempny, Nowicka 2004; 2006). W przypadku zaś antologii, która przywołuje jego pracę (Nowicka, Głowacka-Grajper 2009), udostępniony zostaje Model uniwersum Indian - tekst merytorycznie niewątpliwie istotny, ale nie zapoznający bezpośrednio z zasadą relatywizmu, a przy tym zdolny przytłoczyć nowicjusza swoim rozmachem. Zwraca też uwagę, że w przypadku publikacji Ewy Nowickiej i Małgorzaty Głowackiej-Grajper artykuł Whorfa znalazł się w rozdziale pod tytułem „Psychokulturalizm". Tytuł ten jest oczywistym kompromisem - obok Whorfa w rzeczonym rozdziale zamieszczone są jeszcze prace Edwarda Sapira, Abrama Kardinera, Ralpha Lintona i Margaret Mead. Jednak dla dorobku Whorfa adekwatniejszy byłby termin „psycholingwistyka”, jakkolwiek jego współczesne znaczenie ma niewiele wspólnego ze sposo- 
bem, w jakim terminu tego używał Whorf - i to na długo, zanim rozpropagował go w naukach społecznych John Carroll (Lee 1996: 1-3), późniejszy redaktor klasycznego już zbioru pism Whorfa Language, Thought and Reality. Być może właśnie owo „psycho” sprawia, że socjologów Whorf właściwie nie inspiruje, a nieliczne przypadki zainteresowania nim potwierdzałyby utrwalenie się w socjologii tego trybu recepcji jego dzieł, który wypracowany został z dala od badań socjologicznych (por. Marody 1987). Wtedy jednak znana teza samego Whorfa o wpływie nazwy sytuacji na ludzkie zachowanie potwierdzałaby się w sposób paradoksalny. Tytułowanie stanowiska Whorfa z uwzględnieniem przedrostka „psycho-" (kulturalizm lub lingwistyka) doprowadzałoby do tego, że socjologowie widzieliby u Whorfa niewiele godnego uwagi. Dominujący sposób obchodzenia się z jego dorobkiem utrwalony został przecież na drodze jego „spsychologizowania”, a więc sprowadzenia do tego, co miałoby być sprawdzalne w toku badań psychologii eksperymentalnej (Lee 1996: 27; Edwards 1997: 202-229). W ten sposób pismom Whorfa trwale został przypisany status twierdzeń o ogólnych zdolnościach ludzkiego umysłu: indywidualnych możliwościach przetwarzania informacji, procesach pamięciowych, postrzeganiu i uczeniu się (Lucy 1992: 129). Z tych względów to, co zwykle rozumie się jako "poglądy Whorfa", jest pochodną tego, czego doczytali się $\mathrm{w}$ jego tekstach sympatycy stanowisk raczej psychologiczno-kognitywistycznych niż antropologiczno-społecznych.

Zasada relatywizmu językowego jest tylko jedną z wielu połączonych części, tworzących całościowy układ koncepcyjny. Na to, co Penny Lee (1996) nazywa Whorf theory complex, składa się również między innymi zakres zagadnień dotyczących wzorów kategoryzacji gramatycznej, ale i nierozłącznie z nim związana problematyka niejawnej metafizyki kulturowej. Ni- niejszy artykuł przedstawia propozycję nawiązania do jeszcze innej części tego układu: rozproszonych w różnych publikacjach Whorfa uwag o problemie tak zwanej segmentacji doświadczenia. Problem ten zostanie potraktowany nie tyle jako znalezisko wyjęte $\mathrm{z}$ archiwum minionej epoki, lecz jako żywa inspiracja dla współczesnych badań nad dyskursem.

\section{Segmentacja doświadczenia. Trzy możliwości objaśnienia zjawiska}

Za ogólne objaśnienie bazowej idei segmentacji posłużyć może przykład z Reportu z Yale (Yale Report) - tekstu szkicu sporządzonego przez Whorfa w 1938 roku, ale podpisanego również nazwiskiem George'a Tragera, który miał poddać go - ostatecznie jednak niedokonanej - redakcji (por. Lee 1996: 277; Levinson 2012: xix). Szkic ten nie został umieszczony w opracowanym przez Johna Carrolla wyborze pism Whorfa Language, Thought and Reality. Niemniej jest on interesujący już z tego względu, że Whorf zawarł w nim to, co uważał za swoje ówczesne osiągnięcia i uzupełnił je przedłożeniem swoich bieżących planów badawczych. W uwagach tych Whorf nie wspomina jednak o zasadzie relatywizmu językowego, która stała się jego znakiem rozpoznawczym dopiero po ogłoszeniu jego tekstów o kilka lat późniejszych. Nie oznacza to, że relatywizm językowy był dla Whorfa nieistotny. Oznacza to, że ujęcie tych zainteresowań w postaci zasady relatywizmu językowego jest raczej zwięzłym wyrazem złożonych implikacji wcześniejszych ustaleń, nie zaś idée fixe ich autora. Specyfikę problemu segmentacji doświadczenia przybliżyć można na przynajmniej trzy omówione poniżej sposoby.

Pierwsze przybliżenie problemu segmentacji. Raport ukazał się drukiem dopiero w 1996 roku (Lee 1996), a następnie został włączony do wydania Language, 
Thought and Reality z 2012 roku. Whorf posługuje się w nim następującym przykładem: mówimy „pudełko cygar" (a box of cigars), Indianie Hopi mówią „cygara mnogo umieszczone w środku" (cigars plurally put inside), gdzie "mnogo umieszczone w środku” stanowi jedno określenie. Język angielski sugeruje ograniczony kawałek świata - „pudełko”, niosące ze sobą sugestię możliwej zawartości. Przyimek of czyni nią „cygara”. W wyrażeniu Hopi główną część stanowi określenie „cygara" - uogólniony układ uwewnętrznionej wielości. To, w czego wnętrzu jest ten układ, nie wymaga wzmiankowania (Whorf, Trager 2012: 357). Różnice w zakresie wzorców segmentacji doświadczenia dotyczą przede wszystkim tego, co traktowane jest jako ,jeden” aspekt wyodrębniony z wielości tego, co dane (presentation): „jedno" zjawisko, ,jedna” substancja, ,jedna” niby-całość, i co jest łączone z innymi ,jednostkami", aby następnie mogło to być oddane (representation) w mozaikowym przedstawieniu, które język i kultura przyjmują za oczywistość (Whorf, Trager 2012: 356). Różnice w segmentacji dają o sobie znać nie tylko w wyszukanych i trudnych do uzmysłowienia całościowych wizjach ładu wszechświata, ale również w łatwiej rozpoznawalnych niezliczonych drobiazgach języka i kultury (Whorf, Trager 2012: 356).

Ślady tego sposobu analizy znaleźć można u różnych autorów inspirujących się Whorfem. Problem segmentacji jest między innymi przesłanką antropologicznej teorii tabu sformułowanej przez Edmunda Leacha. W swoim słynnym artykule na ten temat Leach formułuje tezę, że „fizyczne i społeczne otoczenie małego dziecka jest postrzegane przez nie jako kontinuum. Nie zawiera ono żadnych samoistnie oddzielonych od siebie "przedmiotów«" (Leach 1989: 155 [tłum. własne]). Leach przyjął, że socjalizacja dziecka do życia w kulturze polega między innymi na uczeniu go „narzucania na swoje otoczenie pewnej siat- ki rozdzielczej, służącej rozpoznawaniu świata jako złożonego z dużej liczby osobnych "przedmiotów«", z których każdemu odpowiada pewna nazwa" (Leach 1989: 155 [tłum. własne]). Najpierw „otrzymuje się" kategorie językowe - ową siatkę rozdzielczą. Następnie przy jej użyciu wyodrębnia się z doświadczenia odpowiadające jej byty, a następnie stopniowo nabiera się przekonania, że ów rozdział został wymuszony przez świat zewnętrzny. Tym samym nasz świat, lub lepiej - świat dla nas - jest pochodną naszego języka i jest to, zdaniem Leacha, jedyny możliwy kierunek zależności (por. Leach 2010; w sprawie późniejszej krytyki tej argumentacji por. Liberman 1990).

Analizy tego problemu można znaleźć także między innymi w psychologii, szczególnie w jej konstrukcjonistycznych odmianach zainteresowanych zjawiskami dyskursu. Rom Harré i Grant Gillett, posiłkując się ustaleniami psychologii postaci, zwłaszcza Wolfganga Köhlera (1929), twierdza, że to, co nazywamy naszym odrębnym Ja, jest wynikiem powszechnie obowiązujących wzorców wyodrębniania określonej całości (figury) z otoczenia (tła). Tym samym introspekcyjne doświadczanie Ja jako niepowtarzalnego rdzenia indywidualnej tożsamości jest z konieczności uprzednio uregulowane przez te wzorce. Harré i Gillett twierdzą więc, że struktura subiektywności odzwierciedla struktury dyskursu, w którym została ukształtowana (1994: 162-180). Bycie częścią kultury (rozumianej jako kontekst życia codziennego) oznacza pozostawanie w obrębie wpływu określonego języka i istniejących wraz z nim dyskursów. Pewne aspekty doświadczenia mają w nich dla siebie gotowe nazwy i sposoby ekspresji, a inne nie. To z kolei czyni niektóre doświadczenia albo pozbawionymi możliwości uzyskania środków wyrazu, albo bez szans na odszukanie w nich sensu. Część doświadczeń będzie więc nienazywalna i niewyrażalna lub w ogóle nie będzie rozpoznana jako odręb- 
ne doświadczenia. Jednostka nie ma więc, przekonują Harré i Gillett, innej możliwości, jak tylko określić swoje Ja w terminach udostępnionych jej przez kulturę. W komentarzu do stanowiska tych autorów Vivien Burr twierdzi, że słowa mające wyrażać stany wewnętrzne Ja, takie jak „gniew”, „nienawiść” i „zazdrość", są zasadniczo wcześniejsze niż Ja: istnieją i są stosowane przez wcześniejsze pokolenia użytkowników języka, w którym występują. Uczącemu się mówić dziecku nie jest udzielane prawo do decyzji, czy przyjąć je, czy nie. Przyswajając język, może ono nauczyć się rozumienia siebie tylko $\mathrm{w}$ ramach tych słów i tych pojęć (Burr 1995: 23; por. González Rey 2018). O tyle też struktura przyswajanego języka określa strukturę świadomości uczącego się mówić (Burr 1995: 34-35).

Roger Fowler, choć pracujący w ramach lingwistyki strukturalno-systemowej Michaela Hallidaya, przejął antropologiczne zainteresowania językiem do analiz w ramach tak zwanej lingwistyki krytycznej. Inspiracje Whorfem są u Fowlera ewidentne, gdy $\mathrm{w}$ Language in the News przekonuje on, że słownictwo danego języka działa przez segmentację świata i określa sposób jego pojmowania na potrzeby danej kultury (Fowler 1991: 80-85; por. także Fowler i in. 1979). Jakkolwiek Fowler ma bezdyskusyjne zasługi dla powstania jednego z nurtów w ramach badań nad dyskursem - krytycznej analizy dyskursu - to jednak nie obejmują one bliższego wprowadzenia w problematykę segmentacji, którą Whorf stawiał w centrum własnych zainteresowań. Whorf chciał widzieć językoznawstwo jako aspekt etnolingwistyki, będącej w - można powiedzieć interdyscyplinarnym - połączeniu z refleksją nad właściwościami kultury, bez której językoznawca pozbawia się dystansu do własnej problematyki oraz traci podstawy do ujawnienia bazowego sensu językowych części w kulturowej całości (Whorf, Trager 2012: 363-364).
Drugie przybliżenie problemu segmentacji. Dodatkowe objaśnienie problemu segmentacji można znaleźć w przeprowadzonym przez Whorfa omówieniu trzech rodzajów przekładu terminologii i odniesień kulturowych. Pierwszy - przekład oficjalny - dotyczy tego, co nazwa implikuje i co zwykle członkowie danej kultury podają w pierwszej kolejności jako jej wyjaśnienie. Drugi - przekład dosłowny - jest przeprowadzany na podstawie usystematyzowanej wiedzy o gramatyce języka i analizie form jego składowych. Trzeci - przekład interpretatywny - uwzględnia zarówno pogłębione wyjaśnienia formułowane przez członków kultury, jak i wiedzę badacza o tej kulturze. Whorf podaje przykład: oficjalne tłumaczenie terminu paho (pa·hə) w języku Hopi to 'laska modlitewna' (prayer-stick). Przekład dosłowny odsłania dodatkowe znaczenie: przez pah ha należy rozumieć także 'strzałę wzburzonej rzeki' lub 'grot bystrza' (wild-water arrow). Z kolei przekład interpretatywny, pisze Whorf, musiałby być inny bogatszy, ale i trudniejszy do wykonania. Wymagałby wzięcia pod uwagę poglądów religijnych Hopi, uwzględnianego przez nich szczególnego znaczenia 'bystrza' oraz żywiołu wody jako łagodnej, płynnej substancji przeciwstawionej twardości formy stałej. Musiałby ponadto brać pod uwagę kulturowy sens idei łagodnie wdzierającej się strzały (subtle arrow), z którą związane jest wyobrażenie kierowania się w zaświaty (Whorf, Trager 2012: 371).

Whorf posługuje się także przykładem „bagna”, jako określenia stosowanego $\mathrm{w}$ odniesieniu do gruntu o szczególnych właściwościach: „My wydzielamy z doświadczenia pewien element nazywany »bagnem«, nadając mu typową formę rzeczownika. Jako rzeczownik wyraz ten zostaje wtłoczony w koleiny wyżłobione dla wszelkich rzeczowników. Traktujemy go jako językowy odpowiednik »rzeczy«, a więc jako odpowiednik czegoś, co ma swą indywidualną 
odrębność, co może być pojedyncze lub mnogie, co może być $\mathrm{w}$ języku poprzedzone przyimkiem albo zaimkiem wskazującym" (Whorf 1982a: 227). Pojęcie bagna dzieli językowy los obiektywizacji z innymi pojęciami. „»Wzgórze« i »bagno« każą nam traktować lokalne odchylenia wysokości i składu gleby na ziemi jako oddzielne obiekty w rodzaju nieomal stołów i krzeseł" (Whorf 1982b: 341). To, że uzyskują one $\mathrm{w}$ języku postać rzeczownikową, a nie postać pewnej intensywności lub zmiennego nasilenia pewnych jakości, przekłada się, w uznaniu Whorfa, na wzór segmentacji doświadczenia wzgórz i bagien jako odrębnych „kawałków” krajobrazu.

Zajmowanie się kategoriami gramatycznymi danego języka, takimi jak dostępność określonych rzeczowników, liczb (pojedynczej i mnogiej), trybów czy stron, może więc dotyczyć problemu segmentacji, ale nie ujmuje jego pełni. Analiza wyłącznie językowa będzie pomijać ogólniejsze zagadnienie kulturowych mentalności (cultural mentalities), wyrażające się nie tylko w jednostkach kategoryzacji gramatycznej, ale i w niejawnej metafizyce danego syndromu „kultura-język" oraz w subtelnościach atmosfery umysłowej, wyłaniającej się z głębi systemu wartości danej kultury (Whorf, Trager 2012: 362-363). Zaproponowany przez Whorfa termin ethnolinguistics miał oznaczać badania nad tą złożoną wielością: etnolingwista miał być zdolny do opuszczania domeny językowej i w miarę merytorycznie umotywowanych potrzeb badawczych kierować się ku fenomenom przynależnym kulturowej atmosferze umysłowej.

W związku z tym, gdyby problem segmentacji pojmować wyłącznie jako własność języka i tym samym - domenę językoznawstwa, to można byłoby przyznać słuszność George'owi Lakoffowi i Markowi Johnsonowi, twierdzącym, że badania Whorfa wiodą przede wszystkim do banalnej konkluzji, zgodnie z którą kultury różnią się między sobą tylko sposobem językowego „kawałkowania” świata: nazywając go inaczej, odmiennie wyodrębniają z niego części (Lakoff 2011: 306). Przyjęcie tej argumentacji bez zastrzeżeń doprowadziłoby jednakże do zignorowania kulturowych następstw utartego podążania za nakazami segmentacji. Są one czymś znacznie bogatszym w implikacje niż "tylko" kawałkowanie świata, czymś więcej niż relacja między różnorodnością językowej segmentacji a jednorodnością rzeczywistości segmentowanej.

Trzecie przybliżenie problemu segmentacji. Whorf starał się między innymi odpowiedzieć na pytanie: „Czy pojęcia »czasu«, »przestrzeni«, »materii« dane są $\mathrm{w}$ doświadczeniu wszystkim ludziom $\mathrm{w}$ formie zasadniczo tej samej, czy też są częściowo uwarunkowane strukturą poszczególnych języków?" (Whorf 1982c: 187). Uznał, że zakres różnic między językami Indian i językami indoeuropejskimi daje podstawy, aby na użytek analizy porównawczej zgrupować większość języków indoeuropejskich pod łączną nazwą SAE (Standard Average Language) i potraktować je jako wystarczająco do siebie zbliżone, by następnie na ich tle przedstawić właściwości wybranych rdzennych języków amerykańskich. W SAE, pisze Whorf, stosujmy liczebniki główne i liczbę mnogą w odniesieniu do wielości rzeczywistych (czyli postrzegalnych zbiorów przestrzennych), ale również do wielości wyobrażonych. Do wielości rzeczywistych zalicza się taki zbiór, jak "dziesięciu ludzi”, ich bowiem można bezpośrednio spostrzec na ulicy. Przykładem wielości wyobrażonych jest zbiór „dziesięć dni", którego spostrzec obiektywnie nie można. Doświadczyć można najwyżej jednego dnia - dzisiejszego. Whorf wskazuje, że języki SAE dysponują wspólnym językowym wzorcem dla mówienia o obu zbiorach. W związku z tym zbiory te mieszają się ze sobą i wzajemnie upodobniają - byty nieprze- 
strzenne i abstrakcyjne ulegają metaforycznej obiektywizacji. Doświadczenie „dziesięciu ludzi” na ulicy, podobnie jak doświadczenie cyklicznego ciągu dziesięciu kroków naprzód lub dziesięciu uderzeń w dzwon, stają się w SAE wzorcem zapożyczanym do mówienia o zbiorach wyobrażonych.

Whorf argumentuje, że ujednolicenie sposobów mówienia o obu zbiorach, a w związku z tym segmentacja czasu na jednostki takie jak dni, nie bierze się z doświadczenia i to nie ono narzuca sposób językowej ekspresji czasu. Zbiór postrzegalnych bytów przestrzennych i zbiór bytów wyobrażonych upodobniają się w języku, ale tylko pod warunkiem, że jest się użytkownikiem któregoś z języków SAE. W językach tych czas jest zobiektywizowany - jest czymś policzalnym, dającym się wymierzyć, podzielić na odcinki i jednostki podobne do jednostek długości stosowanych w pomiarach przestrzeni fizycznej. Mierzenie „długości czasu”, wskazuje Whorf, traktowane jest przez użytkowników SAE tak, jak mierzenie rzędu podobnych do siebie obiektów, na przykład ustawionych w linii butelek (Whorf 1982c: 188). Rzecz jasna Whorfa nie interesują same przedmioty, tylko sposób ich porządkowania, nie dni, ale relacja, w jakiej są wobec siebie umieszczane. „Cykliczność wywołuje reakcję wyimaginowanej liczby mnogiej. Ale podobieństwo między cyklicznością a zbiorami nie jest czymś danym w doświadczeniu poprzedzającym język - bo musiałoby wówczas tkwić we wszystkich językach; tymczasem rzecz ma się inaczej" (Whorf 1982c: 188). Whorf przekonuje, że w języku Indian Hopi nie istnieją wielości wyobrażeniowe, nie mówi się w nim o „dziesięciu dniach". Zdaniu „Dziesięć dni to więcej niż dziewięć dni” odpowiada zdanie „Dziesiąty dzień jest później niż dziewiąty”. Zamiast o „długości czasu”, mówi się o zależności dwóch wydarzeń pod względem pory ich wystąpienia. W językach SAE dni są ustawiane w rzędzie w postaci wyobrażonej wstęgi ciągnącej się od przeszłości przez teraźniejszość w przyszłość. To, co w nich jest traktowane jak kolejny i za każdym razem nowy dzień, w języku Hopi przypomina raczej jeden dzień pojawiający się niczym gość wielokrotnie odwiedzający to samo miejsce. Kto ulega wrażeniu mistyczności takiej koncepcji czasu, winien, zdaniem Whorfa, rozważyć własną: czas, który upływa, i przestrzeń, która jest nieruchoma, tworzą całość o cechach nie mniej mistycznych niż wiele innych (Whorf 1982d: 100).

Segmentacja nie jest zjawiskiem bez związku z innymi zjawiskami układu kultura-język. Dlatego też współczesne badania nad dyskursem mogłyby skorzystać na sięgnięciu do problematyki segmentacji. Najpierw jednak musiałyby zostać spełnione dwa warunki. Pierwszym - zupełnie podstawowym jest samo wyodrębnienie segmentacji jako sprawy godnej osobnej tematyzacji. Drugim zaś warunkiem jest uwzględnienie sygnalizowanej przez Whorfa konieczności międzydyscyplinarnego badania tego zjawiska. Dla współczesnych badań nad dyskursem oznacza to wskazanie socjologicznej, a nie wyłącznie językoznawczej, istotności segmentacji. Próbie spełnienia tych dwóch warunków poświęcone będą dalsze uwagi.

\section{Od segmentacji doświadczenia do sposobu rozpatrywania. Przykład}

Dyskutowany przez Whorfa problem segmentacji może nabrać socjologicznej istotności z chwilą gdy przestanie się go traktować wyłącznie jako środek analizy tego, co jest dostępne - zwłaszcza niejawnie - w strukturze i gramatyce języka, i zacznie się go pojmować jako środek analizy tego, co dane niejawnie w strukturze wypowiedzi. Gdy jednostką analizy staje się wypowiedź (a nie leksem lub zdanie), środki 
segmentacji przestają mieć wyłącznie charakter językowo-gramatyczny i o ile znajdują społeczne zastosowanie, przekształcają się w aspekty zjawisk dyskursowych. Do ich diagnozy pojęcie segmentacji może być szczególnie przydatne, lecz bez pewnych modyfikacji nie sposób zastosować go poza źródłowym kontekstem. Wprowadzenie tego pojęcia do analizy dyskursu publicznego wymaga podjęcia dodatkowych starań: takiego przetworzenia go, które uwzględni okoliczności obowiązujące w społeczeństwach objętych procesami medializacji życia społecznego. Jednym ze sposobów, w jakie analiza dyskursu mogłaby skorzystać z pojęcia segmentacji, byłoby przeformułowanie go w pojęcie sposobu rozpatrywania.

Jeśli środki segmentacji mają być rozważane w socjologicznej istotności ich publicznych następstw, to trzeba wziąć pod uwagę, że nie są one (po prostu) dostępne w języku, nie są ważne (po prostu) jako wyraz zjawisk kognitywnych, lecz są nieustannie publicznie udostęniane, a sposób ich jawnej obecności ma implikacje dla życia zbiorowego i jego przeobrażeń. Możliwości interdyscyplinarnego użytku z problemu segmentacji doświadczenia otwierają się w chwili, gdy przestaje się ujmować ów problem wyłącznie na sposób podpowiadany $\mathrm{w}$ literaturze z zakresu współczesnej etnolingwistyki lub filozofii umysłu. Dziedziny te posługują się często wzorcem językowo wyposażonego indywiduum konfrontującego się ze światem, dokonującego „kawałkowania” swojego własnego doświadczenia, obcującego z bezpośrednio dostępnym otoczeniem. Przejście od problemu segmentacji do problemu sposobu rozpatrywania każe uwzględnić okoliczności całkiem odmienne, mianowicie kontekst publicznego rozpowszechniania określonych środków interpretacji na cudzy użytek.

W różnych okolicznościach medialnego zapośredniczenia wiedzy eksperci instruują innych, jaki sens mają pewne doświadczenia, zachwalają określone poglądy, prezentują się jako tak zwani praktycy zaznajomieni z realiami życia instytucjonalnego. Eksperci upowszechniają więc kwalifikowane wypowiedzi jako zgodne z doświadczeniem, formułują podpowiedzi w sprawie tego, co inni mogą lub powinni robić we własnym życiu jako odpowiadające zbiorowemu doświadczeniu, ogłaszają fachowe porady prezentowane jako oparte na założeniu istnienia odbiorcy, który te głosy odbiera, rozpoznaje w swoim środowisku i ewentualnie je uwzględnia. W związku z tym zgodność między medialnie zapośredniczoną wypowiedzią a osobistą wiedzą i doświadczeniem nadawcy jest tych wypowiedzi założeniem: i to tyleż nieoczywistym, co koniecznym dla roszczeń do uznania fachowości wskazówek rozpowszechnianych właśnie jako fachowe.

Zjawisko to ujawnia pełnię swych problematycznych implikacji we współczesnej kulturze dyskursu publicznego, dla której ludzkie życie wewnętrzne dawno przestało być wymiarem prywatności tych, którzy je wiodą. Przeciwnie - psyche pracowników, zarządców, obywateli, rodziców, pacjentów, uczniów i wielu innych jest zagadnieniem omawianym jawnie i powszechnie, sferą otwartą dla ingerencji wychowawczych, oświatowych i instruktażowych (Czyżewski, Marynowicz-Hetka, Woroniecka 2013; Petersen, Millei 2016; Ostrowicka 2019). Psyche jest także celem praktyk intensyfikacji współzawodnictwa w obrębie pracy klas średniej i wyższej (Mokrzan 2019). Wiedza o psyche jest już nieodzowną instancją rządzenia (Rose 1999), którą stała się między innymi dzięki uznaniu jej za podstawę niedyrektywnych sposobów prowadzenia podwładnych (Bogołębski 2014; Musílek 2015). W tym kontekście dziedzina psychologicznego znawstwa nie ma żadnych cech kustoszki zbiorów ludowej kultury duchowej, nie przypomina też przewodniczki po niedostępnościach duszy. Między innymi dzięki 
swemu powiązaniu z dyskursem zarządczym (Stachowiak 2017) stała się raczej częścią głównego nurtu tak zwanych nauk o zarządzaniu - zajęła się w równej mierze kształtowaniem pożądanego postępowania indywidualnego i zbiorowego, co maskowaniem absurdalności wielostronnych nierówności społecznych (por. Sułkowski, Zawadzki 2014). Zarządczo użyteczna wiedza o psyche stanowi obecnie dyscyplinę przyczyniającą się do legitymizacji ideału spełnionego obywatela i konsumenta (Matysek-Imielińska 2016), poszerzając zakres wpływu idei neoliberalizmu daleko poza sam neoliberalny język filozoficzny i ekonomiczny (por. Markiewka 2017).

Jak poddać obserwacji ów podstawowy fenomen współczesnej kultury kapitalizmu, jakim jest sposób rozpatrywania psyche podwładnych? Jak ro- zeznać się w jego właściwościach? Potrzebny jest przykład, w którym swoisty dla psychologicznego znawstwa planistyki pracy sposób rozpatrywania spraw podwładnych ujawni się w dostatecznie wyraźnych konturach. Niżej przywołany fragment wypowiedzi doradczej pochodzi z tekstu Iwony Bobrowskiej-Budny pod tytułem Każdy ma talent. Dlaczego warto tworzyć kulture organizacyjna sprzyjajaca rozwojowi talentów wszystkich pracowników, a nie tylko wybranych? Poradnik ten został opublikowany w numerze specjalnym „Personel i Zarządzanie” wydanym na dwudziestopięciolecie tego czasopisma. Do poniższej analizy został on wybrany z obszernego zbioru materiałów analizowanych w badaniach nad przemianami planistyki pracy (Stachowiak w druku). W tekście Bobrowskiej-Budny znalazł się między innymi następujący fragment:
1.

2.

3.

4.

5.

6.

7.

8.

9.

10.

11.

12.

13.

14.

15.

16.

17.

18.

19.

20.

21.

22.

23.

24.

25.

26.

27.

28.
Istnieje kilka definicji słowa „talent”. Na przykład Instytut Gallupa sformułował na podstawie mocnych stron człowieka definicję talentu jako każdego powtarzającego się wzorca myślenia, odczuwania lub zachowania, które może mieć pozytywne zastosowanie. Natomiast Model S dr Kingi Padzik z Akademii Leona Koźmińskiego wyodrębnia rdzeń modelu kompetencji stworzony z elementów osobowości, które dla każdego człowieka są trwałe i trudno poddają się zmianie. Na osi rdzenia osadzamy spontanicznie lub intencjonalnie $\mathrm{w}$ procesie uczenia: wiedzę, doświadczenie oraz zdobywane umiejętności i uprawnienia. Dzięki zrozumieniu swojego rdzenia wiemy, które z nich wpasowują się $\mathrm{w}$ nas naturalnie, a które są „nie nasze” i wymagają dużego nakładu czasu oraz pracy dla ich uzyskania, o ile w ogóle jest to możliwe. [...]

W dzisiejszych czasach nie mamy czasu na nieustanną stymulację pracowników motywatorami zewnętrznymi. Jeśli organizacja nie skupi się na tworzeniu przestrzeni wspierającej wewnętrzną motywację pracownika, umożliwiającą mu rozwój kompetencji, zbierania doświadczeń i rozwoju talentów zgodnych z "posiadanym rdzeniem”, jego zaangażowanie może maleć oraz jego szybkość odczuwania zmęczenia będzie wzrastać, negatywnie wpływając na poziom wykonania zadań. Czyli brak zaangażowania nie jest związany z brakiem kompetencji, tylko z niewykorzystaniem naturalnych predyspozycji danej osoby, dotarciem do tego, co w naturalny sposób przychodzi mu najłatwiej. Brak świadomości, jakie predyspozycje i potencjał mają poszczególni pracownicy, może spowodować nieświadome blokowanie chęci pełnego wykorzystania możliwości ludzi na korzyść organizacji.

Instytut Gallupa potwierdza badaniami, że talenty każdej osoby są trwałe i wyjątkowe, a największa przestrzeń do rozwoju człowieka to obszar jego najsilniejszych stron. Aby zobrazować tę koncepcję, wystarczy wybrać dowolny przedmiot szkolny, który nie był naszą mocną stroną i przypomnieć sobie, ile czasu musieliśmy poświęcić, żeby "się do niego zabrać" i zaliczyć na oczekiwanym poziomie, oraz jak niewspółmierne do nakładów pracy wyniki osiągaliśmy. W efekcie często też zaniżając samoocenę, widząc, jak innym przychodziło to bezwysiłkowo. (Bobrowska-Budny 2019: 26) 
Fragment ten został wyłoniony do analizy ze względu na trzy ogólne kryteria. Pierwszym z nich jest kryterium społecznej istotności tekstu dla środowiska, którego on dotyczy (Czyżewski i in. 2017: 16). Wybrany tekst spełnia to kryterium w dwójnasób. Każdy ma talent ukazał się w jednym z najważniejszych w Polsce periodyków specjalistycznych poświęconych problematyce zarządzania, doradztwa i wiedzy z zakresu kierowania pracą - wydawanym od 26 lat „Personelu i Zarządzaniu”. Zgodnie z opisem redakcyjnym czasopismo skierowane jest do dyrektorów i menedżerów personalnych, pracowników działów szkoleń i rozwoju, właścicieli firm, prezesów zarządów, wykładowców uczelni i studentów, a także wszystkich osób zainteresowanych tematyką zarządzania kapitałem ludzkim (PiZ 2020). Ponadto redakcja „Personelu i Zarządzania" sama dowartościowała znaczenie tej publikacji, ogłaszając ją w specjalnym wydaniu czasopisma pod tytułem „Programy rozwojowe dla firm. Jak je projektować, by były skuteczne?". Ponadto redakcja umieściła zdjęcie autorki wraz z reklamą jej firmy na pierwszej i czwartej stronie okładki. Są to miejsca szczególnie ważne dla promocji periodyku: przeznacza się je dla wizualnego opisu handlowego, który ma kształtować oczekiwania czytelnicze wobec sprzedawanych treści.

Drugim ogólnym kryterium spełnianym przez ten tekst jest jego socjologiczna istotność dla analizy związków między pojedynczą wypowiedzią a ogólnymi zjawiskami dyskursowymi. To kryterium jest spełniane przez wybrany poradnik również w dwojaki sposób. Pod formalnymi i treściowymi względami wpisuje się on bowiem w szerszy fenomen dyskursowy określany mianem „nowego ducha kapitalizmu”. Luc Boltanski i Ève Chiapello, którzy - w nawiązaniu do prac Maksa Webera - wprowadzili termin „nowego ducha kapitalizmu” do słow- nika nauk społecznych, wskazują, że właśnie tego rodzaju teksty są areną współczesnej wiedzy doradczej, diagnoz zarządczych i eksperckiej wiedzy o pracującym podwładnym. W znaczącym zakresie współtworzą one ideologię, która uzasadnia zaangażowanie w kapitalizm i czyni to zaangażowanie atrakcyjnym (Boltanski, Chiapello 2012). Zajęcie się wybranym materiałem i umiejscowienie go w obrębie nadal publicznie prawomocnej ideologii nowego ducha kapitalizmu jest więc szansą na to, aby za pośrednictwem mikroanalizy tekstu rozpoznać niektóre z ogólniejszych własności dyskursowych planistyki pracy dzisiejszej doby.

Jest bowiem sprawą całkiem zrozumiałą, że obecny w wybranym fragmencie swoisty sposób rozpatrywania psyche wyłonił się i znajduje publiczny użytek w obrębie kultury kapitalizmu - to potwierdza już samo zaistnienie przytoczonego przykładu. Kultura ta dodatkowo sama się dyskursywizuje: usilnie dowartościowuje znaczenie zarządczo przydatnych mówców, konsultantów, doradców i coachów, a zarazem nieoczekiwanie nabiera rysów bufonady (grandiosity, por. Alvesson 2013), w której rządzi retoryka doskonałości, pasji, sukcesu i odkrywania osobistego potencjału. Dyskursywizacja kultury kapitalizmu dostarcza więc racji za sensownością podporządkowywania jej socjologicznej analizie, ale również za czynieniem sposobu rozpatrywania pełnoprawnym punktem badawczego odniesienia.

Autorka analizowanego tekstu zostaje w piśmie zaprezentowana jako „Talent management mentor, trener biznesu i wykładowca akademicki". Taka formuła przedstawienia autorki sygnalizuje jeszcze inny wymiar makrospołecznych przeobrażeń współczesności. Jest nim zacieranie się granic między światem wiedzy i instytucji akademickich a światem wiedzy i instytucji pozaakademickich. 
Każdy ma talent jest właśnie jednym z przejawów tego - by użyć słów Everetta Hughesa - jednego z podstawowych problemów naszych czasów (1993: 410-411). Hughes zawracał uwagę na zjawisko wkraczania w świat uniwersytecki zawodów (occupations) chcących uchodzić za profesje (professions). $Z$ jednej strony, twierdzi Hughes, w poszukiwaniu uzasadnienia swojej działalności przedstawiciele tych zawodów przekonują zwykle, że opierają się na jakiejś dyscyplinie akademickiej lub na wiedzy naukowej. Planistyka pracy jest pod tym względem szczególnie wyrazistym przykładem działalności zawodowej, próbującej profesjonalizować się przez poszukiwanie legitymizacji w wiedzy psychologicznej. Z drugiej zaś strony sam Hughes wskazuje właśnie na psychologię jako przedstawicielkę dyscyplin naukowych, które twierdzą, że są w istocie profesjami i kierują swoją uwagę poza świat akademicki. Tekst z zakresu wiedzy o psyche, napisany na użytek fachowej obsługi świata pracy, może uzmysłowić, czym publicznie chwalą się tak zwani eksperci „pracujący z ludźmi” oraz w jaki sposób "ludzkie sprawy" rozpatrywane są przez profesjonalistów (w sensie Hughesa), którzy prezentują się jako przedstawiciele świata akademickiego.

Trzecim ogólnym kryterium jest to, co można byłoby nazwać moca porównawczą przykładu. Wybrany tekst jest obdarzony wystarczającą mocą porównawczą, a więc wystarczająco wyraziście ukazuje ogólne własności sposobu rozpatrywania, aby można było porównywać z nim inne wypowiedzi, w których te własności albo nie ujawniają się dość jasno, albo występują w ograniczonym zakresie. Innymi słowy, rozważany tu przykład może posłużyć jako punkt orientacyjny dla dalszych badań nad różnymi wariantami i zastosowaniami tego, co w rozważanym niżej tekście ujawnia się szczególnie dobitnie.

\section{Analiza sposobu rozpatrywania}

Bezdyskusyjnie w przypadku prowadzenia analiz takich materiałów jak Każdy ma talent niezbędna jest wielokrotna, niespieszna i eksplorująca lektura. Takiego postępowania wymaga nie tylko formułowanie uwag i uogólnień. Wymaga jej przede wszystkim samo rozeznanie się w swoistości uporządkowania wypowiedzi, której domniemana zrozumiałość i rzekoma nieproblematyczność skłaniałyby do dopasowywania własnego sposobu czytania cudzej strategii pisania. Ze względu na to, że fragment ten ma służyć rozpoznaniu formalnych własności sposobu rozpatrywania psyche podwładnych, uwagi analityczne powinny być ukierunkowane na uniknięcie dwóch okoliczności. Z jednej strony na przeciwdziałanie atomistycznemu „szufladkowaniu” (Czyżewski 2008: 26), czyli odnotowywaniu wyłącznie detali językowych lub retorycznych, z drugiej zaś strony - zadowalaniu się komentarzami utrzymanymi w stylistyce streszczenia. Analiza ma umożliwić rekonstrukcję wzoru dyskursowego (Potter, Wetherell 1987: 168), w jaki układają się dane, oraz ma uwzględnić jego implikacje i następstwa. Taki sposób konceptualizacji badań towarzyszy różnym nurtom interpretatywnym $w$ naukach społecznych, między innymi etnometodologii (Pollner 1987; Garfinkel 2007), konstrukcjonistycznym badaniom problemów społecznych (Spector, Kitsuse 1987; Holstein, Miller 1993) czy psychologii dyskursowej (Edwards 2012; Wiggins 2017). Jest również obecny w Whorfiańskiej tradycji antropologii lingwistycznej. Cel badań jest następujący: rozeznanie się $\mathrm{w}$ swoistości środków, z użyciem których to, o czym jest wypowiedź, tworzone jest jako obiekt naszego rozumienia (Edwards 1997: 45). Jednym $z$ takich środków jest właśnie sposób rozpatrywania. Służy on za podstawę nazywa- 
nia, objaśniania, przekształcenia lub legitymizacji tego, co jego użytkownicy sami uznają za sprawy wymagające takich działań.

Tłem analizy sposobu rozpatrywania psyche nie są więc różnice międzykulturowe w zakresie segmentacji dokonywanej z użyciem odmiennych języków, tylko swoistość środków dyskursowych w zakresie jednej kultury i jednego języka (tu: polskiego). Przy czym własności sposobu rozpatrywania nie dają się ustalić według kryteriów socjologii języka lub socjolingwistyki, jeśli rozumieć pod tymi nazwami badania nad środowiskowym zróżnicowaniem narodowego języka oraz relacjami odmian języka narodowego do struktury społecznej (Handke 2008: 13; por. Piotrowski, Ziółkowski 1976; Coupland, Sarangi, Candlin 2001). Sposób rozpatrywania nie jest aspektem językowej charakterystyki żadnej grupy społecznej z osobna. Socjologiczny wymiar zjawisk, z którymi jest związany, ujawnia się o tyle, o ile istnieją określone środki interpretacyjne - nie grupy społeczne. Bez wątpienia centralne zagadnienie zaangażowania podwładnych $\mathrm{w}$ pracę jest $\mathrm{w}$ przywołanym fragmencie sformułowane jako problem rządzących, nie zaś rządzonych, a konieczność „zajęcia się” tym zagadnieniem wyrażona jest w imię celów "góry" hierarchii instytucjonalnej (elity władzy organizacyjnej), a nie „dołów”. Tekst Bobrowskiej-Budny należy do dyskursu elit symbolicznych. Władza elit symbolicznych nie jest władzą polityczno-instytucjonalną, lecz władzą w obrębie kulturowo-normatywnej kontroli nad dyskursem publicznym - jego kształtem i treściami (Czyżewski i in. 2014: 8).

Sposób rozpatrywania, którego zastosowaniem jest ten fragment, można ogólnie określić jako taką procedurę porządkowania wypowiedzi, która instruuje o domniemanych formalnych własnościach tego, czego ma dotyczyć treść wypowiedzi. Innymi słowy, sposób rozpatrywania jest jawnie, ale pośrednio, udzielaną odpowiedzią na niejawne pytania: „z czym mamy do czynienia?” i „co jest do zinterpretowania?". Właśnie o tym, czym owo "coś" jest, mówią sami doradcy - to jest sprawa dla nich ważna, ale i ważna dla ich publicznego autorytetu. Dlatego między innymi analiza powinna stawiać sobie za cel opisanie, czym owo „coś” jest dla uczestników dyskursu. Analiza dyskursu nie jest zaś ani zdolna, ani zobowiązana do przesądzania czegokolwiek w sprawie ewentualnej natury tego "czegoś". Termin psyche - wraz ze swą ogólnością i swoistą obcością - przychodzi więc analizie z pomocą. Wspiera ją tylko $\mathrm{w}$ tym zakresie, $\mathrm{w}$ jakim potrzebne jest pokazanie kierunku eksperckich zainteresowań, aspiracji i poznawczych roszczeń. Jednak czym w istocie jest to, co eksperci w swoim mniemaniu znajdują w umysłach, duszach lub sercach podwładnych - o tym termin psyche już nie ma orzekać. Używanie określeń takich jak „świadomość", "tożsamość” lub „psychika” zakładałoby zbyt wiele $\mathrm{w}$ sprawach będących zjawiskami dopiero wymagającymi rozpoznania.

Zatem w analizie rekonstruowany będzie ten wzór wypowiedzeniowy, z którego użyciem psychologiczne znawstwo planistyki pracy objaśnia psyche podwładnych, a następnie umożliwia sobie eksperckie doradzanie $\mathrm{w}$ jej sprawie oraz pośrednio przypisuje swojemu poradnictwu fachowość i prawomocność.

Struktura przytoczonego fragmentu umożliwia wytyczenie podziału strukturalnego w jego obrębie. Linie $1-10^{1}$, zwierające treści przedstawione w stylistyce informacyjnej, skupione są na tak zwa-

${ }^{1}$ Liczby w nawiasach to odwołania do numeracji wersów. 
nym 'Modelu $\mathrm{S}^{\prime 2}$. Linie 11-21, utrzymane w formacie doradztwa, zawierają instrukcję, co i jak robić z podwładnymi. Linie 22-28 mają charakter argumentacyjny i poświęcone są wyłożeniu dowodu słuszności całej wypowiedzi. Na podstawie analizy tego fragmentu można sformułować szereg uwag na temat ogólnego wzorca sposobu rozpatrywania.

\section{Kontrast - podział dwuczęściowy. Jako okoliczność} problemowa zdefiniowane zostaje 'zaangażowanie' pracowników. O ile mówi się o nim jak o kłopocie zarządczym, to znaczy takim, który nie uwzględnia jeszcze eksperckiej wiedzy psychologicznej, o tyle 'zaangażowanie' objaśniane jest $\mathrm{z}$ użyciem podziału dwuczęściowego. Jedną częścią są 'pracownicy', drugą zaś jest to, co w swoistym sensie znajduje się na zewnętrz 'pracowników': 'czas', którego 'nie mamy', 'stymulowanie', 'motywatory zewnętrzne' (11-12).

2. Wyodrębnienie ustosunkowania - podział trzyczęściowy. Psychologiczne znawstwo planistyki pracy zmienia dwuczęściowy podział na preferowany przez siebie podział trzyczęściowy. Trzecia część zostaje wydzielona z 'pracowników'. Jest to składowa, którą na użytek analizy można nazwać ustosunkowaniem. Ustosunkowanie jest dziedziną tego, co dla znawców psyche wyznacza gotowość podwładnego do działania zgodnego z oczekiwaniami. Odpowiednie ustosunkowanie poprzedza więc działanie. $W$ analizowanym fragmencie do ustosunkowania należą 'zaangażowanie' i 'chęci'. Ustosunkowanie rozpatrywane jest tak, jakby znajdowało się w nim wszystko to, co przesądza o gotowości podmiotu do określonego prowadzenia się, co w związku z tym poprzedza

${ }^{2}$ Cudzysłów apostrofowy (") będzie tu wykorzystany do oznaczenia sformułowań zaczerpniętych z zapisu. zewnętrznie obserwowane działanie podmiotu i jest warunkiem osiągnięcia korzyści z jego pracy. Odpowiednie ustosunkowanie do działania jest objaśniane jako ta część psyche, od której zależy możliwość uzewnętrznienia tego, co ma znajdować się przed nim, czyli przed 'zaangażowaniem' i 'chęcią' do pracy. To, co w szczególnym sensie znajduje się głębiej w psyche, to 'wiedza, doświadczenia oraz zdobywane umiejętności i uprawnienia' (7). Znawstwo psyche jednoznacznie rozróżnia dziedzinę ustosunkowania i tego, co przed nim (16-17). Dzięki temu retoryka behawioryzmu ('stymulacja pracowników motywatorami zewnętrznymi', 11-12) ustępuje retoryce psychologii pozytywnej (12 i nast.). Rozczłonkowywanie sytuacji problemowej na trzy części: dwie umiejscawiane $\mathrm{w}$ psyche (ustosunkowanie i to, co przed nim) oraz część tego, co za ustosunkowaniem (na zewnątrz podwładnego) jest zasadniczym, wielokrotnie odtwarzanym i na różne sposoby wykorzystywanym aspektem sposobu rozpatrywania, z użyciem którego psychologiczne znawstwo planistyki pracy formułuje swoje poradnictwo. Wykazuje się ono przy tym niewyczerpaną pomysłowością $\mathrm{w}$ zakresie dalszych podziałów, typologii i szczegółowych kategoryzacji różnych aspektów ustosunkowania oraz definicji tego, co ma zajmować miejsce przed ustosunkowaniem.

3. Ustosunkowanie zgodne i niezgodne z oczekiwaniami. W tym konkretnym przykładzie ustosunkowanie 'pracowników' do działania rozpatrywane jest jako przyjmujące dwa warianty. Pierwszy, który można byłoby nazwać ustosunkowaniem zgodnym z oczekiwaniami, to 'zaangażowanie' (15) oraz 'chęć wykorzystania możliwości' (20). Drugi wariant wyznacza ustosunkowanie niezgodne z oczekiwaniami: 'odczuwanie zmęczenia', które 
'wpływa na poziom wykonania zadań' (15-16) oraz 'zaangażowanie', które 'może maleć' (15).

\section{Uszeregowanie wyróżnionych części. Sposób rozpa-} trywania umożliwia takie objaśnianie sytuacji problemowej, jak gdyby wyróżnione w niej trzy części były uporządkowane szeregowo, jedna po drugiej: najpierw to, co przed ustosunkowaniem, następnie - „za nim” - samo ustosunkowanie, i dalej to, co na zewnętrz podwładnego.

W wielu przypadkach używanie czterech dotychczas wskazanych aspektów ogólnego wzorca jest psychologicznemu znawstwu w pełni wystarczające do publicznego objaśniania źródeł i możliwości zaradzenia nieodpowiedniej pracy podwładnych. Publiczne objaśnienia psyche posługują się nieraz złożonymi typologiami aspektów ustosunkowania, ale nie przedstawiają szczegółowej charakterystyki tego, co przed nimi (na przykład odnosząc się do nich, poprzestają na zastosowaniu ogólnej kategorii „kapitał ludzki”). Czasem zaś to aspekty ustosunkowania omawiane są bardziej skrótowo, za to w większych szczegółach przedstawiane jest to, co w szeregowym porządku ma się znajdować przed nimi. Tak właśnie jest $\mathrm{w}$ analizowanym przypadku. To, co przed ustosunkowaniem, jest w nim omawiane w taki sposób, jak gdyby samo było dodatkowo (wewnętrznie) złożone. Sposób rozpatrywania owej złożoności jest taki, że czyni z tego, co przed ustosunkowaniem miniaturę objaśnianej trzyczęściowej całości - osobną szkatułkę w większej szkatule. Stosując ponownie ten sam wzorzec szeregowego uporządkowania, psychologiczne znawstwo skupia się na części centralnej, mającej łączyć to, co przed nią z tym, co za nią. Częścią centralną staje się 'motywacja wewnętrzna' (13). To, co przed nią zostaje wyróżnione jako 'posiadany rdzeń' (14) i 'oś rdzenia' (6), a więc całość 'stworzona z elementów osobowości'
(4-5). To zaś, co za 'motywacją wewnętrzną', to ‘wiedza, doświadczenie oraz zdobywane umiejętności i uprawnienia' (7), a więc to, co można 'uzyskać' (9) i co ‘wpasowuje się w nas naturalnie' (8).

5. Idea ruchu zachodzacego w psyche. Doradztwo eksperckie wprowadza ideę ruchu między wyodrębnionymi i szeregowo rozmieszczonymi częściami. Ruch ten ma rozpoczynać się przed ustosunkowaniem i wieść na zewnętrz. W związ$\mathrm{ku}$ z tym ustosunkowanie zgodne z oczekiwaniami ten ruch umożliwia: umiejscowione w psyche 'predyspozycje i potencjał' (19) mogą zostać uzewnętrznione i już poza psyche mogą być 'wykorzystane' na 'korzyść organizacji' (16, 21). Z kolei ustosunkowanie niezgodne $z$ oczekiwaniami 'blokuje' ruch, przez co 'możliwości ludzi' (20) nie są $\mathrm{w}$ stanie ujawnić się na zewnętrz. Ruch tego, co 'zgodne $\mathrm{z}$ posiadanym rdzeniem' do przodu i na zewnątrz (zarówno w "szkatułce”, jak i w całej „szkatule”) jest okolicznością oczekiwaną i pożądaną. Ruch zatrzymany wymaga przywrócenia.

6. Sterowanie ruchem zachodzacym w psyche. Pozytywność, praktyczność i optymalizacyjna użyteczność doradztwa wiążą się bezpośrednio z sugestią możliwości ruchu „w głąb” psyche, w tym przypadku na możliwości 'dotarcia do tego, co w naturalny sposób przychodzi mu [podwładnemu - przyp. JS] najłatwiej' (18). Tym samym bezpośrednia przydatność psychologicznego znawstwa wiąże się z obietnicą przywrócenia ruchu od wewnątrz na zewnątrz - z możliwością „wydobycia” tego, co w szeregowym porządku jest „zatrzymane przed" ustosunkowaniem niezgodnym z oczekiwaniami. Tak więc skupione na „odblokowywaniu” ruchu doradztwo ekspertów od psyche pojmuje swoją rolę jako rodzaj 
działalności udrożniającej. Doradztwo sugeruje możliwość przywrócenia ruchu -,odblokowania" tego, co przed ustosunkowaniem. Sugestia ta stanowi podstawę zachęt do objęcia przez 'organizację' uwagą 'motywacji wewnętrznej' podwładnych. Kierunek oddziaływania psychologicznego ma być więc przeciwny do kierunku „wydobywania” z podwładnych domniemanego potencjału.

W sprawie tego sposobu rozpatrywania ważne stają się nie tylko pytania o to, co jest przyjmowane za jeden „kawałek” sytuacji problemowej i jaka jest domniemana natura zależności między „kawałkami”. Można też pytać: jaki w tych wszystkich sprawach zostaje dokonany wybór spośród możliwych alternatyw? Psychologiczne znawstwo planistyki pracy nie dopuszcza przecież, aby psyche była chaosem, nie przewiduje również, aby miało do czynienia z amalgamatem niezróżnicowanych subiektywnych jakości. Psyche nie jest też traktowana jako językowo niewyrażalna, niepomierna sekwencja zmiennych intensywności ogólnego stanu ducha. Psyche jawi się nie tylko jako dziedzina językowo wyrażalna, ale też jako dająca się porządkować według czytelnego wzoru kojarzonego z zarządczą racjonalnością. W poszczególnych przypadkach wypowiedzi eksperckich wynik rozbioru psyche może być w wybranych aspektach różny, ale pozostaje ściśle związany z sugestią optymalizacji życia wewnętrznego. Sugestia ta bazuje na publicznie zrozumiałych wzorcach obchodzenia się z obiektami materialnymi.

„Psychologiczność" tego typu wiedzy planistycznej jest więc zasadniczo dwuznaczna. Ukazuje psychologiczne znawstwo jako instancję techniki zastosowanej do pracy psyche (por. Stachowiak w druku). Ów swoiście techniczny sposób rozpatrywania psyche ujawnia się w podanym przykładzie jako zapowiedź dwukierunkowych prac wydobywczych: udrożniania „kapitałowi ludzkiemu” drogi „na zewnątrz", a tym samym zyskiwania dostępu do ludzkich „zasobów”. Krótko mówiąc, mamy tu do czynienia z tym, co można byłoby nazwać metodą psychologii wydobywczej. Jest ona stosowana do udzielania odpowiedzi na kolejne pytania: „co inni mają »w sobie«?", „,co uniemożliwia dotarcie do tego czegoś?", „co uniemożliwia wydostanie się tego czegoś na zewnątrz?", „jak możliwe jest uzewnętrznienie z psyche tego, co w niej jest i czego oczekuje otoczenie?". Metoda ta ustanawia więc psyche całością podzieloną tak, aby dawało się wyróżnić to, co jest „,W" ludziach, a przy tym jest potrzebne na zewnątrz, oraz to, co jest „,W" ludziach, lecz stanowi „blokadę". Szeregowy układ części psyche i idea ruchu z „wnętrza” psyche na zewnętrz występują tu w połączeniu z sugestią możliwości udrożnienia przepływu i skanalizowania tego, co musi znaleźć ujście. Tak oto czyni się psyche podlegającą fachowemu rozbiorowi, w tej postaci ustanawia się ją poznawalną i dającą się „z zewnątrz” optymalizować. Metoda objaśniania psyche ma jednak swój pierwowzór w działalnościach całkiem innych i gdzie indziej znalazła najszersze zastosowania. Obecna jest między innymi w technologii sięgania po surowce naturalne, ale pojawia się też $\mathrm{w}$ technologiach tworzenia systemów wodociągowych (dostarczanie, odbiór, przewodzenie wody) czy budowy silników spalinowych (przekształcanie energii w pracę urządzenia). Objaśnienia dwukierunkowego ruchu dostawania się do nich („surowców” w psyche) i wykorzystywania ich (po wydobyciu) nie wprowadza istotnych różnic formalnych między pracą z ludźmi a pracą $z$ rzeczami. $W$ ten sposób psychologiczne znawstwo radzi $w$ podwójnym sensie: radząc innym w sprawie 'blokad' i ograniczeń w 'dostawaniu' się do 'potencjału', radzi też sobie z publicznym 
zaświadczaniem o fachowości swojej wiedzy i racjonalności swoich zaleceń.

Opublikowanie tekstu Każdy ma talent (co więcej w wydaniu specjalnym czasopisma) potwierdza publiczną prawomocność psychologicznego znawstwa tego rodzaju. W tym kontekście stosowane przez Nikolasa Rose'a określenie engineers of the human soul (1999), którego autorstwo Rose przypisuje skądinąd Józefowi Stalinowi, nabiera nowej, konkretnej treści. Ale sformułowanie pojęcia sposobu rozpatrywania ma za zadanie nie tyle jeszcze raz potwierdzić, że współczesna planistyka pracy zainteresowana jest psyche - ma raczej pomóc w postawieniu „kolejnego kroku”. Ma przysłużyć się zwróceniu uwagi na problematykę techniki pojmowaną w inny sposób niż w reprezentowanej przez Rose'a tradycji postfoucaultowskiej. W tej bowiem tradycji zagadnieniem naczelnym jest rządzenie, zaś technika rządzenia oznacza ogół środków służących kształtowaniu ludzkiego postępowania. Sposób rozpatrywania dotyczy innego, jakkolwiek niesprzecznego z wnioskami Rose'a, problemu. Można go streścić następująco: psychologiczne znawstwo planistyki pracy jawnie i w sposób zwykle niekontestowany korzysta z metod objaśniania psyche, które znajdują swój pierwowzór $\mathrm{w}$ dziedzinie technicznego obchodzenia się z obiektami wymiernymi, uchwytnymi i namacalnymi.

Mimo to „psychologiczność” objaśnień zawartych w przywołanym przykładzie (i wielu podobnych) uchodzi zwykle za, by użyć sformułowania Whorfa, non est disputandum. Odpowiada ona na zapotrzebowanie planistyki pracy, która nie tworzy przecież ani ścisłego systemu wiedzy, ani ustalonego zasobu słownictwa specjalistycznego. Między innymi dzięki temu sposób rozpatrywania psyche podwładnych znajduje w planistyce pracy rozmaite zastosowania, a własności jego ogólnego wzoru wykorzystywane są w różnym zakresie. Określeniem „potencjał” oznacza się niekiedy aspekty ustosunkowania, niekiedy zaś w ten sposób mówi się o tym, co „poprzedza" ustosunkowanie (por. Warszycka 2013: 42-45). Czasem doradztwo zainteresowane jest wyłącznie "ruchem” do środka, a więc ' docieraniem" do czegoś, czego podwładny ma wbrew oczekiwaniom wobec niego nie uzewnętrzniać. Innym razem tematem fachowego poradnictwa jest wyłącznie „ruch” na zewnątrz. W takim przypadku zadaniem tak zwanego eksperta staje się „usuwanie blokad” rozwojowych, „zrzucanie nakładek” ze „sposobu myślenia” i „uruchamianie prawdziwego potencjału” (por. Kądzielski-Zysk 2016: 57-61). Nieraz psychologiczne znawstwo wypowiada się w sprawie aspektów ustosunkowania jak o tym, co poprzedza zdobywanie „kompetencji” i umożliwia ich bezpośrednie uzewnętrznienie (por. Gołacka 2012: 84-87). Ta wielorodność zastosowań utrudnia rozeznanie się $\mathrm{w}$ sposobie rozpatrywania i jego formalnych własnościach. Zarazem jednak właśnie ta różnorodność pozwala uzmysłowić sobie zakres wypowiedzeniowej użyteczności sposobu rozpatrywania dla wszystkich tych, którzy żyją z tak zwanej optymalizacji wykorzystania własnych zasobów, zmieniania nieproduktywnych nawyków czy budowania samoświadomości.

Podobne przykłady są interesujące nie dlatego, że zostały podpisane nazwiskami przedstawicieli szczególnej grupy zawodowej, ani też dlatego, że ich analiza miałaby upoważniać do rzucania oskarżeń na tych, którzy jako dziedzinę swojej publicznej aktywności zdecydowali się wybrać zarządzanie lub przedsiębiorczo użyteczne poradnictwo psychologiczne. $W$ istocie poznawcze zadania niniejszej analizy nie dotyczą ani tej lub innej osoby, która miałaby stać „za” tekstem, ani 
demaskacji czegoś, co przez te osoby miałoby być ukrywane. Całkowitym nieporozumieniem byłoby również przyjęcie, że analiza sposobu rozpatrywania dociera do doświadczenia ludzi (np. pracowników), których dotyczy ten lub inny tekst doradczy, i w związku z tym właśnie owo doświadczenie należy uznać za ostateczny test poznawczych walorów analizy. Cel jest inny: rozpoznanie metod służących tym, którzy życzą sobie uchodzić za znawców psyche, do tematyzacji, objaśnienia, uzasadnienia czy opisania tego, co sami publicznie przedstawiają jako ludzkie doświadczenie. Nie sposób więc sprowadzić analizy sposobu rozpatrywania, podobnie jak części innych form badania relacji między wypowiedziami a działaniami społecznymi³ ${ }^{3}$ wyłącznie do analizy lingwistycznej. Problem tkwi nie w samym języku, lecz również w społecznie usankcjonowanych praktykach porządkowania jego kategorii. Nie da się też zamknąć tej problematyki w ramach wybranego nurtu klasycznej antropologii, a to ze względu na społeczno-historyczne skutki psychologizacji i dyskursywizacji świata pracy. Jeden z nich wiąże się z problematyką cywilizowania uprzedmiotowienia i wymaga osobnego omówienia.

\section{Badania nad dyskursem wobec cywilizowania uprzedmiotowienia}

Wśród konsekwencji publicznie akceptowanego i na ogół niekwestionowanego użytku z tego sposobu rozpatrywania jest następowanie szczególnego historycznego procesu przekształceń dyskursowych, który można określić mianem cywilizowania uprzedmiotowienia (Stachowiak w druku). W toku tego procesu uprzedmiotowienie przestaje być de-

${ }^{3}$ Por. uwagi Emanuela Schegloffa (1991) na temat związku analizy konwersacyjnej z badaniami nad strukturą społeczną. pozytariuszem wyłącznie nowych "form utowarowienia ciała pracującego" (Szarecki 2017: 174). Uprzedmiotowienie uzyskuje nową postać: inną od wzorców z czasem moralnie zdyskwalifikowanego traktowania ludzi jak "dodatku do maszyny”. Postać ta jest dopasowana do ideału zdemokratyzowanych relacji społecznych i konieczności uznania podmiotowości podwładnych. Zarazem nośnikiem cywilizowania uprzedmiotowienia nie jest tayloryzm i jego pochodne z początku XX wieku, lecz przeciwnie: jest nim między innymi dziedzina przedsiębiorczo użytecznej wiedzy o psyche, która od swego zarania propagowana była jako alternatywa wobec tak zwanego naukowego zarządzania i jako krzewicielka nowych standardów poznawczych, moralnych i zarządczych.

Przeniesienie wzorców techniki i inżynierskiej optymalizacji pracy do dziedziny wiedzy o psyche zdaje się dziś najzupełniej dopuszczalne i umożliwia kojarzenie wykształcenia psychologicznego z dogłębną znajomością rzeczy [sic!]. W techniczności sposobu rozpatrywania psyche daje się rozpoznać nieusunięty i być może nieusuwalny aspekt świata kapitalistycznej pracy, do którego psychologia jako wiedza specjalna przystąpiła na długo po inżynierii. Gwarantowana wiedzą o psyche humanizacja pracy nie jest koniecznością stosunków pracy, nie jest też wyznacznikiem kulturowego postępu. Ale powinowactwa współczesnego dyskursu zarządczego z uprzedmiotowieniem nie stwierdzają korporanci wchodzący z nim w bezpośrednią styczność (Stachowiak 2019). Dla nich dyskurs ten podporządkowany jest najwyżej niepotrzebnej manierze, sztucznie tworzącej nieprzystępność, która odbiera miejsce komunikacyjnej zwyczajności. Dyskursowe własności współczesnej planistyki pracy nie są przez nich rozważane $\mathrm{w}$ kategoriach uprzedmiotowienia i humanizacji, lecz w kategoriach dwóch 
repertuarów interpretacyjnych: repertuaru konwencjonalności i bezpretensjonalności (Stachowiak 2019). Podobnie próżno oczekiwać potwierdzenia związków wiedzy psychologicznej z uprzedmiotowieniem wśród jej rzeczników. Już to dlatego, że leżą one poza spektrum ich fachowych zainteresowań, już to dlatego, że sami eksperci deklarują świadczenie usług $\mathrm{w}$ imię pomocy ludziom w samodoskonaleniu.

A jednak zaznacza się frapujące powinowactwo między sposobami rozumienia własnej misji doradczej przez tak zwanych ekspertów od psyche a celami wytyczonymi inżynierom-doradcom w obrębie tradycji zarządczej rozpropagowanej przez Fryderyka W. Taylora w jego Zasadach organizacji naukowej zakładów przemysłowych (1923). Rozdźwięk między inżynierią a psychologią, jakkolwiek na pierwszy rzut oka szczególnie ewidentny, słabnie wraz z uwzględnieniem, że to właśnie planistyka pracy sama na różnych etapach swoich przekształceń ów kontrast zaciera. Przykład kontrastowy może dać pewne wyobrażenia o kierunku cywilizowania uprzedmiotowienia, które wiedzie od jego form już dziś nieprawomocnych do jego form cieszących się publiczną dopuszczalnością. W 1928 roku w "Przeglądzie Organizacji”, a więc $\mathrm{w}$ czasopiśmie polskich kontynuatorów tak zwanego naukowego zarządzania, ogłoszono tekst autorstwa Stefana Twardo pod tytułem Wyścig pracy w dziedzinie administracji państwowej. Artykuł ten brzmi wystarczająco egzotycznie, by po latach zwrócić na niego uwagę, a zarazem jest wystarczająco bliski współczesnemu sposobowi rozpatrywania psyche podwładnych, by wzmóc dociekania porównawcze. $W$ tekście tym można znaleźć wypowiedź, utrzymaną w duchu inżynierii fabrycznej, w której radzi się organizatorom pracy biurowej, jak doskonalić „,załatwianie spraw”:
W płaszczyźnie organizacji pracy, każda sprawa przepływająca przez urzędy może być traktowana analogicznie do materjału surowego, z którego fabryka wytwarza przedmiot użytkowy. Obywatel zgłaszający sprawę jest tym interesantem dającym zamówienie, które ze swej surowej początkowej fazy wychodząc, poddane poszczególnym operacjom dochodzi do stadjum ostatecznego załatwienia. Analogicznie - jak $\mathrm{w}$ fabryce odbywa się proces wytwarzania, polegający na umiejętnem przekształceniu surowców, - tak w biurach urzędów odbywa się proces załatwiania sprawy [...]. Rozważny współzawodnik bada każdą śrubkę swej maszyny, która ma mu przynieść zwycięstwo $\mathrm{w}$ wyścigu, stara się $\mathrm{w}$ drobiazgach nawet zwiększyć szanse zwycięstwa. A wyścig, o którym mowa, współzawodnictwo na polu pracy państwowo twórczej, wyścig na maszynach marki »administracja państwowa« to rzecz niełatwa [...]. (pisownia oryginalna - przyp. JS; Twardo 1928: 217-218)

W wypowiedzi przedstawiciela tak zwanego naukowego zarządzania nie istnieją żadne zasadnicze różnice między pracą biura a fabryczną obróbką surowców. Te zaś, na które Twardo wskazuje, są przez niego umyślnie pomniejszane, aby nie przeczyły tezie, iż naukowe zarządzanie administracją jest zasadniczo tylko inną postacią inżynierii. Rozwinięta z czasem psychologia pracy znalazła dla siebie własny obiekt zainteresowania, ale nie odstąpiła od techniki inżynierskiej jako koncepcyjnej zasady.

Owszem, w filozoficznych i socjologicznych nurtach tradycji marksowskiej znane są argumenty za tezą, iż kultura kapitalizmu cechuje się „postępującą kolonizacją ciała przez kapitał" (Szarecki 2017: 237). Ale badania nad dyskursem umożliwiają poprowadzenie tych refleksji dalej. Pozwalają rozpoznać techniczny format uprzedmiotowienia w dziedzinie znawstwa, które uchodzi za przeciwieństwo 
utowarowienia i kolonizacji pracowników. Mowa tu więc o odmianie uprzedmiotowienia, która z ciałem podwładnych związana jest tylko pośrednio, a tym samym tylko pośrednio łączy się z formami uprzedmiotowienia znanymi z obszarów pracy fizycznej. O ile cywilizowanie uprzedmiotowienia niesione jest psychologicznym znawstwem planistyki pracy, o tyle oznacza ono proces publicznego uprawomocnienia metod psychologii wydobywczej.

Znawcy psyche chcą mówić o obiektywnych własnościach psychologicznych człowieka, ale zarazem publicznie korzystają z wzorców wypowiedzeniowych, których bazowym punktem odniesienia nie jest podwładny - osoba, podmiot. Mnogość terminologii, którą zwykło się kojarzyć z psyche, oczywiście jest w użyciu, jednak w nadającym tej terminologii podstawowym sposobie rozpatrywania psyche nie ma niczego, co byłoby szczególnie ludzkie. Tematem nie są ludzie, ale to, co ma być „w nich” i na co współczesna kultura pracy zgłasza nadzwyczajne zapotrzebowanie. Doradztwo dotyczy czegoś, co ma znajdować się gdzieś „,we wnętrzu” podwładnego i czemu drogę do organizacyjnych korzyści należy utorować przez przebudowę ustosunkowania do pracy. Uprzedmiotowienie, polegające na zainteresowaniu wybraną cechą człowieka, a nie człowiekiem jako całością (Nussbaum 1995; Haslam i in. 2008; Bauer 2011), zostaje tu w szczególny sposób spotęgowane. Oznacza to, że w tej mierze, w jakiej uprzedmiotowienie podlega cywilizowaniu, nie dotyczy ono ludzi. Dotyczy raczej tego, co rzekomo znajduje się w ich „wnętrzu” - tego, czego podwładni są jedynie, by tak rzec, nosicielami.

Swoistość „psychologiczności” tej psychologii nie polega jednak na tym, że domniemana praca zachodząca w psyche jest użyteczna lub też, że jej aspekty dają się pojąć jako obiekty rozporządzania. Polega raczej na tym, że psyche podwładnych zostaje wypowiedziana w sposób, który następnie umożliwia doradzanie $\mathrm{w}$ jej sprawie zgodnie z kulturowym wizerunkiem inżyniera. Tak oto kapitalistyczny użytek z techniki, który przez lata oskarżany był o degradację ludzkiego wymiaru pracy (por. Stachowiak 2014), staje się częścią neoliberalnej perswazji (por. Mokrzan 2019). Tym samym psychologiczne znawstwo nie zrywa z inżynieryjnym podejściem do pracy, tylko jawiąc się jako jego odwrotność, kontynuuje jego tradycję. Cywilizowanie uprzedmiotowienia staje się więc kulturowo istotne nie tylko dlatego, że wpływa na przemiany prawomocnych form władzy. Jest ono ważne także dlatego, że techniczny wzorzec zdaje się zaspokajać intelektualne zapotrzebowanie znawców psyche. W tej mierze, w jakiej do tego zaspokojenia dochodzi, cywilizowanie uprzedmiotowienia stanowi czynnik ryzyka nie tyle dla pracowników, co dla niektórych form samopoznania i obcowania z rzeczywistością. Wśród nich są takie, które mimo swojej wielowymiarowości, nieraz celowej nielogiczności i umyślnej sprzeczności z kryteriami zdrowego rozsądku, współczesne psychologiczne znawstwo wprowadza do obiegu kultury kapitalizmu jako szczególnie przedsiębiorczo przydatne. Otóż metoda psychologii wydobywczej jest w dyspozycji tej samej profesji, która promuje biznesową użyteczność praktyk medytacyjnych; która hasło „uważność” pojmuje jako opis środków „zwiększania efektywności” biznesmena; dla której zen to sposób na dbanie o „zasoby energii”. Czy tym właśnie jest medytacja? Czy tym właśnie jest zen? A może właśnie tego od nich chce nowoczesna planistyka pracy?

\section{A priori wypowiedzi i koncepcje pogranicza. Zakończenie}

Pojęcie sposobu rozpatrywania pomyślane jest jako kategoria pośrednicząca między etnolingwistyką 
a analizą dyskursu. W związku z tym sposób rozpatrywania, pojmowany jako kategoria analityczna, może potencjalnie znaleźć $\mathrm{w}$ analizie dyskursu tak szerokie zastosowanie, jak pojęcie językowej segmentacji doświadczenia znalazło $\mathrm{w}$ badaniach inspirowanych etnolingwistyką, a pojęcie dyskursu w naukach społecznych. Zarazem jednak, w niniejszym studium, ta sama kategoria sposobu rozpatrywania, ale pojmowana już jako nazwa zjawiska społecznego, musi zostać wyraźnie ograniczona. Otóż dla analizowanego wyżej fragmentu tekstu przewidziana jest rola ilustracji. Ma ona za zadanie posłużyć ukazaniu możliwości wykorzystania kategorii sposobu rozpatrywania $\mathrm{w}$ analizie empirycznej w szczególnej dziedzinie dyskursu publicznego, jakim jest dyskurs ekspercki. Eksploracja sposobów rozpatrywania $w$ innych dziedzinach wymagałyby więc odmiennych ilustracji.

Analiza sposobu rozpatrywania nie jest w zamierzeniu analizą retoryki, aktów perswazji lub ideologizacji publicznego języka. Zarazem ani ich nie wyklucza, ani im nie przeczy, ani nie jest z nimi niezgodna. Przywołany fragment można byłoby bowiem poddać także innym typom analizy. Można byłoby między innymi zwrócić uwagę na format założonego odbiorcy tekstu - kim są owi „my”, którzy nie mają czasu na 'motywowanie pracowników', i czym jest 'organizacja', na której korzyść zużytkowane mają być 'możliwości ludzi'. Uzasadniona byłaby także analiza językowych wykładników rodzaju tekstu (genre'u) - językowych środków formułowania tekstu doradczego, łączącego przestrogę przed ryzykiem z instruktażem zaradczym. Ale analiza sposobu rozpatrywania nie może skupiać się wyłącznie na zjawiskach języka, takich jak metafora czy terminologia specjalistyczna. Na odpowiednim poziomie ogólności oczywiście wszystkie badania tego rodzaju dają się ze sobą zestawiać, a niekiedy nawet do pewnego stopnia godzić. Analiza sposobu rozpatrywania mierzy jednak nie w zjawisko czysto językowe, ale w szczególnym sensie pozajęzykowe, to znaczy takie, które z socjologicznie istotnych względów wiedzie do refleksji nad tym, co można nazwać dyskursowym a priori wypowiedzi. Analiza sposobu rozpatrywania pojmowana jako badanie metod porządkowania danych językowych w wypowiedziach pozwala tym samym na rozważenie możliwości badań nad kulturową metafizyką psychologicznego znawstwa. Pojęcie sposobu rozpatrywania oraz dotychczasowe prace nad rekonstrukcją cywilizowania uprzedmiotowienia podpowiadają, że historycznych źródeł tej metody należy szukać w dziedzinie inżynierii, a jej formalnego wzorca $\mathrm{w}$ technice.

Można rzecz jasna argumentować, że zainteresowanie owym a priori niebezpiecznie, a zarazem niepotrzebnie, wyprowadza badania nad dyskursem z kręgu nauk społecznych i prowadzi je ku filozofii. Jeśli nawet tak się dzieje, to być może jest to koszt niezbędny do poniesienia w chwili, gdy analiza zaczyna dotykać społecznych granic języka - bazowych reguł życia codziennego i zasadniczych założeń dyskursowych. Skoro właśnie te granice, reguły i założenia mają zostać objęte analizą, wówczas badanie musi się liczyć z tym, że nabierze filozoficznych rysów i będzie musiało posłużyć się abstrakcją. Whorf celowo przesuwał horyzont językoznawstwa i antropologii ku metafizyce, ale nie dla niej samej, tylko dla uchwycenia obserwowalnego $\mathrm{w}$ strukturach językowych „poglądu na świat” danej kultury. Socjologia nieraz czyni podobnie. Przykładem klasycznym są badania Melvina Pollnera nad tak zwanym rozumem potocznym (1987) - kierowaniem się przez uczestników życia codziennego założeniem istnienia wspólnego, zewnętrznego i obiektywnego świata, które ludzie przyjmują i na różne sposoby nieustannie sobie po- 
twierdzają (Pollner 1974). I Whorf, i Pollner hołdowali ideałowi nieustannego oddzielania od siebie języka analizowanego od języka analizy. Ideał ten popycha językoznawstwo i socjologię ku miejscom ich styku z pojęciowością filozofii i skłania te dyscypliny do wytwarzania koncepcji pogranicza ('marginal' ideas, por. Pollner 1987: xiii).

Próba przetworzenia problematyki segmentacji w problematykę sposobu rozpatrywania i włączenia jej do interdyscyplinarnych badań nad dyskursem społeczeństw współczesnych ma więc wieloraki sens. Dzięki jej podjęciu możliwy staje się powrót do dorobku Whorfa, ale bez konieczności psychologizacji wynikających z niego wniosków i bez forsowania określonych epistemologicznych implikacji zasady relatywizmu językowego. Warto więc sięgnąć do Whorfa antropologa badającego kultu-

\section{Bibliografia}

Alvesson Mats (2013) The Triumph of Emptiness. Consumption, Higher Education, and Work Organization. Oxford: Oxford University Press.

Bartmiński Jerzy (2012) Jezykowe podstawy obrazu świata. Lublin: Wydawnictwo Uniwersytetu Marii Curie-Skłodowskiej.

Bauer Nancy (2011) Beauvoir on the Allure of Self-Objectification [w:] Charlotte Witt, ed., Feminist Metaphysics. Dordrecht: Springer Science+Business Media B.V., s. 117-129.

Bobrowska-Budny Iwona (2019) Każdy ma talent. Dlaczego warto tworzyć kulture organizacyjna sprzyjajaca rozwojowi talentów wszystkich pracowników, a nie tylko wybranych? „Personel i Zarządzanie”, nr 8, wydanie specjalne: Programy rozwojowe dla firm, s. 24-29.

Bogołębski Tomasz (2014) Coaching w optyce rządomyślności - próba krytycznej analizy zjawiska [w:] Marek Czyżewski i in., rowo utarte sposoby używania języka (por. Chatterjee 1985; Lucy 1992; Kienpointner 1996; Edwards 1997), nie zaś wyłącznie do Whorfa językoznawcy uchylającego okno do ludzkiego umysłu (Pinker 2008). Rzecz więc nie w tym, aby wyzbyć badania nad dyskursem centralnej dla Whorfa problematyki kulturowej metafizyki (Whorf 1982d: 98-107), tylko w tym, aby jej implikacje dla teorii poznania zrównoważyć ustaleniami w zakresie teorii kultury. Problem segmentacji doświadczenia był dla Whorfa zagadnieniem interdyscyplinarnym, z wyodrębnialnym aspektem językowym (badanym przez językoznawstwo) i kulturowym (badanym przez antropologię). W zawiązku z tym sposób rozpatrywania jako problem badawczy mógłby również pozostać problemem pogranicza. To właśnie w tej postaci może on być szczególnie przydatny interdyscyplinarnym badaniom nad dyskursem.

red., Dyskurs elit symbolicznych. Próba diagnozy. Warszawa: Wydawnictwo Akademickie SEDNO, s. 173-196.

Boltanski Luc, Chiapello Ève (2012) Le nouvel esprit du capitalisme. Paris: Gallimard.

Burr Vivien (1995) An Introduction to Social Constructionism. London and New York: Routledge.

Chatterjee Ranjit (1985) Reading Whorf Through Wittgenstein. A Solution to the Linguistic Relativity Problem. „Lingua”, vol. 67, s. 37-63.

Coupland Nikolas, Sarangi Srikant, Candlin Christopher N., eds. (2001) Sociolinguistics and Social Theory. Essex: Pearson Education Limited.

Czyżewski Marek (2008) Elementy i całości. O niektórych dylematach analizy dyskursu [w:] Anna Horolets, red., Analiza dyskursu 
w socjologii i dla socjologii. Toruń: Wydawnictwo Adam Marszałek, s. 19-29.

Czyżewski Marek, Marynowicz-Hetka Ewa, Woroniecka Grażyna (2013) Pedagogizacja życia społecznego. „Societas/Communitas" nr 2/16.

Czyżewski Marek i in., red. (2014) Dyskurs elit symbolicznych. Próba diagnozy. Warszawa: Wydawnictwo Akademickie Sedno.

Czyżewski Marek i in., red. (2017) Analiza dyskursu publicznego. Przeglad metod i perspektyw badawczych. Warszawa: Wydawnictwo Akademickie Sedno.

Edwards Derek (1997) Discourse and Cognition. London, Thousand Oaks, New Delhi: Sage Publications.

Edwards Derek (2012) Discursive and scientific psychology. „British Journal of Social Psychology", no. 51, s. 425-435.

Everett Daniel (2013) Linguistic Relativity. Evidence Across Languages and Cognitive Domains. Berlin, Boston: Walter de Gruyter.

Fowler Roger (1991) Language in the News. Discourse and Ideology in the Press. London: Routledge.

Fowler Roger i in. (1979) Language and Control. London: Routledge \& Kegan Paul.

Garfinkel Harold (2007) Studia z etnometodologii. Przełożyła Alina Szulżycka. Warszawa: Wydawnictwo Naukowe PWN.

Głaz Adam, Danaher David, Łozowski Przemysław (2013) The Linguistic Worldview. Ethnolinguistics, Cognition, and Culture. London: Versita.

Godlewski Grzegorz i in. (2001) Antropologia kultury. Zagadnienia $i$ wybór tekstów. Warszawa: Wydawnictwa Uniwersytetu Warszawskiego.

Gołacka Kamila (2012) Krystalografia Diamentów. Jak dobrać ludzi do programu rozwoju talentów? "Personel i Zarządzanie”, nr $11 / 272$, s. $84-87$.

González Rey Fernando (2018) Subjectivity and discourse: Complementary topics for a critical psychology. „Culture \& Psychology", vol. 25/2, s. 178-194.

Grzegorczykowa Renata, Pajdzińska Anna, red. (1996) Jezzykowa kategoryzacja świata. Lublin: Wydawnictwo Uniwersytetu Marii Curie-Skłodowskiej.
Gumperz John, Levinson Stephen, red. (1996) Rethinking linguistic relativity. Cambridge: Cambridge University Press.

Handke Kwiryna (2008) Socjologia języka. Warszawa: Wydawnictwo Naukowe PWN.

Harré Rom, Gillett Grant (1994) The Discursive Mind. Thousand Oaks, London, New Delhi: Sage Publications.

Haslam Nick i in. (2008) Attributing and denying humanness to others. „European Review of Social Psychology”, no. 19, s. 55-85.

Holstein James A., Miller Gale (1993) Reconsidering social constructionnism. Debates in social problems theory. New Brunswick, London: Aldine Transaction.

Hołówka Teresa (1986) Myślenie potoczne. Heterogeniczność zdrowego rozsadku. Warszawa: Państwowy Instytut Wydawniczy.

Hughes Everett (1993) The sociological eye. Selected Papers. New Brunswick, London: Transaction Publishers.

Kądzielski-Zysk Piotr (2016) Zarzadzanie przez docenianie czyli nowa koncepcja motywowania a mentalność pracowników. „Personel i Zarządzanie", nr 5(314), s. 57-61.

Kempny Marian, Nowicka Ewa (2004) Badanie kultury. Elementy teorii antropologicznej. Warszawa: Wydawnictwo Naukowe PWN.

Kempny Marian, Nowicka Ewa (2006) Badanie kultury. Elementy teorii antropologicznej. Kontynuacje. Warszawa: Wydawnictwo Naukowe PWN.

Kienpointner Manfred (1996) Whorf and Wittgenstein. Language, World View and Argumentation. "Argumentation", vol. 10, s. $475-494$.

Köhler Wolfgang (1929) Gestalt Psychology. New York: Liveright.

Lakoff George (2011) Kobiety, ogień i rzeczy niebezpieczne. Co kategorie mówia nam o umyśle. Kraków: Universitas.

Leach Edmund (1989) Anthropological Aspects of Language: Animal Categories and Verbal Abuse. "Anthrozoös" vol. 2/3, s. $151-165$.

Leach Edmund (2010) Symboliczne uporzadkowanie świata tworzonego przez człowieka: granice w społecznej przestrzeni i czasie [w:] Edmund Leach, Kultura i komunikowanie. Warszawa: Wydawnictwo Naukowe PWN, s. 780-787. 
Lee Penny (1996) The Whorf Theory Complex: A Critical Reconstruction. Amsterdam: John Benjamins.

Levinson Stephen C. (2012) Foreword [w:] John B. Carroll, Stephen C. Levinson, Penny Lee, eds., Language, Thought, and Reality: Selected Writings of Benjamin Lee Whorf (Second Edition). Cambridge: The MIT Press, s. vii-xxiv.

Liberman Anatoly (1990) Reactions to Edmund Leach's "Anthropological Aspects of Language" and John Halverson's "Animal Categories and Terms of Abuse". "Anthrozoös", vol. 3:4, s. $214-226$.

Lucy John (1992) Language Diversity and Thought. A Reformulation of the Linguistic Relativity Hypothesis. New York, Melbourne: Cambridge University Press.

Markiewka Tomasz Szymon (2017) Język neoliberalizmu. Filozofia, polityka i media. Toruń: Wydawnictwo Naukowe Uniwersytetu Mikołaja Kopernika.

Marody Mirosława (1987) Technologie intelektu. Jezykowe determinanty wiedzy potocznej i ludzkiego działania. Warszawa: Państwowe Wydawnictwo Naukowe.

Matysek-Imielińska Magdalena (2016) Od klasy robotniczej do klasy kreatywnej. Narracje o sukcesie i niespetnieniu [w:] Wojciech Józef Burszta, Piotr Jezierski, Michał Rauszer, red., Zwodnicze imaginarium. Antropologia neoliberalizmu. Gdańsk: Wydawnictwo Naukowe Katedra, s. 421-450.

Mokrzan Michał (2019) Klasa, kapitał $i$ coaching w dobie późnego kapitalizmu. Perswazja neoliberalnego urzadzania. Toruń: Wydawnictwo Naukowe Uniwersytetu Mikołaja Kopernika.

Musílek Karel (2015) Nurturing the Worker's Self: The Ethic of Authenticity in The Discourse of Professional Self-Development [w:] Marjan Ivković, Gazela Pudar Draško, Srđan Prodanović, eds., Engaging Foucault. Belgrade: Institute for Philosophy and Social Theory, s. 22-36.

Nowicka Ewa, Głowacka-Grajper Małgorzata (2009) Świat człowieka - Świat kultury. Antologia tekstów klasycznej antropologii. Warszawa: Wydawnictwo Naukowe PWN.

Nussbaum Martha C (1995) Objectification. „Philosophy and Public Affairs", vol. 24/4, s. 249-279.

Ostrowicka Helena (2019) Regulating Social Life. Discourses on the Youth and the Dispositif of Age. London, New York: Palgrave Macmillan.
Petersen Bendix, Millei Zsuzsa, eds. (2016) Interrupting the Psy-Disciplines in Education. London, New York: Palgrave Macmillan.

Pinker Steven (2008) The Stuff of Thought: Language as a Window into Human Nature. New York: Penguin Books.

Piotrowski Andrzej, Ziółkowski Marek (1976) Zróżnicowanie językowe a struktura społeczna. Warszawa: Państwowe Wydawnictwo Naukowe.

PiZ (2020) O magazynie [dostęp 1 marca 2020 r.]. Dostępny w Internecie: 〈https://personel.infor.pl/index.php?act=o_magazynie».

Pollner Melvin (1974) Mundane Reasoning. „Philosophy of the Social Sciences", vol. 4, s. 35-54.

Pollner Melvin (1987) Mundane Reason. Reality in everyday and sociological discourse. Cambridge: Cambridge University Press.

Potter Jonathan, Wetherell Margaret (1987) Discourse and social psychology. Beyond attitudes and behariour. London, New Delhi: Sage Publications.

Rose Nikolas (1999) Governing the Soul. The Shaping of the Private Self. London, New York: Free Association Books.

Schegloff Emanuel A. (1991) Reflections on Talk and Social Structure [w:] Deirdre Boden, Don H. Zimmerman, eds., Talk and Social Structure. Studies in Ethnomethodology and Conversation Analysis. Berkeley, Los Angeles: University of California Press, s. 44-70.

Spector Malcolm, Kitsuse John I. (1987) Constructing social problems. New York: Aldine de Gruyter.

Stachowiak Jerzy (2014) O koncepcji nowego ducha kapitalizmu w ujęciu Luca Boltanskiego i Ève Chiapello. „Przegląd Socjologiczny", nr 63/4, s. 9-43.

Stachowiak Jerzy (2017) Analiza porządków uzasadniania. Studium nowego ducha kapitalizmu [w:] Czyżewski Marek, Otrocki Michał, Piekot Tomasz, Stachowiak Jerzy, red., Analiza dyskursu publicznego. Przeglad metod i perspektyw badawczych. Warszawa: Wydawnictwo Akademickie SEDNO, s. 373-402.

Stachowiak Jerzy (2019) Zarządcy o dyskursie zarzadczym. Badania nad regułami krytyki eksperckich wzorców komunikowania publicznego. „Przegląd Socjologiczny”, nr 68(3), s. 95-122.

Stachowiak Jerzy (w druku) Czynnik ludzki. O cywilizowaniu uprzedmiotowienia. Warszawa: Wydawnictwo Akademickie SEDNO. 
Sułkowski Łukasz, Zawadzki Michał, red. (2014) Krytyczny nurt zarządzania. Warszawa: Difin.

Sweeney John Marcus (2009) I'd Rather Be Dead Than Be a Girl: Implications of Whitehead, Whorf, and Piaget for Inclusive Language in Religious Education. Lanham: University Press of America.

Szarecki Artur (2017) Kapitalizm somatyczny. Ciało $i$ władza w kulturze korporacyjnej. Warszawa: Wydawnictwa Drugie.

Tabakowska Elżbieta, red. (2001) Kognitywne podstawy języka i jezzykoznawstwa. Kraków: Universitas.

Taylor Fryderyk (1923) Zasady organizacji naukowej zakładów przemystowych. Warszawa: Wydawnictwo „Ligi Pracy”.

Twardo Stefan (1928) Wyścig pracy w dziedzinie administracji państwowej. „Przegląd Organizacji”, nr 8, s. 217-221.

Warszycka Elżbieta (2013) Niewidoczny potencjał. Jak zdefiniować i zidentyfikować talenty w firmie? "Personel i Zarządzanie” nr 5(278), s, 42-45.

Whorf Benjamin Lee (1982a) Technika psychologii postaci w założeniach szawni [w:] Benjamin Lee Whorf, Język, myśl i rze- czywistość. Warszawa: Państwowy Instytut Wydawniczy, s. 216-234.

Whorf Benjamin Lee (1982b) Język, umyst i rzeczywistości [w:] Benjamin Lee Whorf, Język, myśl i rzeczywistość. Warszawa: Państwowy Instytut Wydawniczy, s. 332-362.

Whorf Benjamin Lee (1982c) Zwiazek między nawykami myślenia i zachowaniem a językiem [w:] Benjamin Lee Whorf, Język, myśl i rzeczywistość. Warszawa: Państwowy Instytut Wydawniczy, s. 181-215.

Whorf Benjamin Lee (1982d) Model »universum « Indian [w:] Benjamin Lee Whorf, Język, myśl i rzeczywistość. Warszawa: Państwowy Instytut Wydawniczy, s. 98-107.

Whorf Benjamin Lee, Trager George Leonard (2012) Appendix: The "Yale Report": Report on Linguistic Research in the Department of Anthropology of Yale University for the Term September 1937 June 1938 [w:] John B. Carroll, Stephen C. Levinson, Penny Lee, red., Language, Thought, and Reality: Selected Writings of Benjamin Lee Whorf (Second Edition). Cambridge: The MIT Press, s. 345-376.

Wiggins Sally (2017) Discursive Psychology. Theory, Method and Applications. London: Sage.

\title{
Cytowanie
}

Stachowiak Jerzy (2020) Czym jest psyche podwładnych dla jej znawców? Benjamin Lee Whorf, pojęcie sposobu rozpatrywania i problem uprzedmiotowienia. „Przegląd Socjologii Jakościowej”, t. 16, nr 4, s. $18-41$ [dostęp dzień, miesiąc, rok]. Dostępny w Internecie: 〈www.przegladsocjologiijakosciowej.org〉. DOI: http://dx.doi.org/10.18778/1733-8069.16.4.02

\section{What Is Subordinates' Psyche for Experts in It? Benjamin Lee Whorf, the Notion of the Way of Considering, and the Problem of Objectification}

\begin{abstract}
This paper argues that discourse studies could benefit from using some of the concepts fostered by Benjamin Lee Whorf. Whorf is not a typical inspiration for discourse analysts. However, Whorf's elaborations on the segmentation of experience could contribute to the thematization of important phenomena in the modern culture. Yet, the concept of segmentation cannot be straightforwardly borrowed from Whorf's ethnolinguistics. It has to be substantially respecified so that it can become useful for modern public discourse studies. As a result of such a respecification, a concept of 'the way of considering' is introduced. Next, an example of textual analysis is demonstrated. It is meant to indicate the meaning and a possible empirical use of the notion of the 'way of considering'. The analysis covers a fragment of advisory text on the psychology of work. The paper concludes with remarks on the process of the civilizing of objectification, particularly with regard to the relationship between the way of considering the subordinates' psyche and the macrosocial transformation of public discourse.
\end{abstract}

Keywords: discourse, objectification, Benjamin Lee Whorf, psychology, capitalism 